\title{
Acritarchs and prasinophytes of the Silurian-Devonian GSSP (Klonk, Barrandian area, Czech Republic)
}

\author{
RAINER BROCKE, OLDŘICH FATKA \& VOLKER WILDE
}

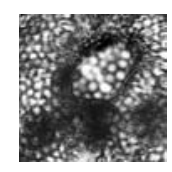

\begin{abstract}
At the GSSP for the Silurian-Devonian boundary at Klonk, Czech Republic, a comparatively poorly diversified palynomorph assemblage has been documented. The boundary interval is characterized by the predominance of thickand/or thin-walled prasinophytes (Leiosphaeridia spp., ?Pleurozonaria spp.), while the other organic-walled microfossil groups are relatively rare (chitinozoans, acritarchs, scolecodonts, certain prasinophytes, mazuelloids). The highest taxonomic diversity of palynomorphs has been documented in the uppermost Přídolí and in the lower part of the Lochkovian. Such a pattern of distribution could be connected with transgressive and regressive pulses occurring at the boundary interval. $\bullet$ Key words: Silurian-Devonian boundary, acritarchs, prasinophytes, mazuelloids.
\end{abstract}

BRocke, R., FATKA, O. \& WILDE, V. 2006. Acritarchs and prasinophytes of the Silurian-Devonian GSSP (Klonk, Barrandian area, Czech Republic). Bulletin of Geosciences 81(1), 27-41. Czech Geological Survey, Prague. ISSN 1214-1119. Typescript received September 15, 2003; accepted in revised form January 12, 2006; issued March 31, 2006.

Rainer Brocke, Research Institute Senckenberg, Palaeobotany, Senckenberganlage 25, D-60325 Frankfurt am Main, Germany; Rainer.Brocke@senckenberg.de• Oldřich Fatka, Charles University, Institute of Geology and Palaeontology, Albertov 6, 12843 Prague 2, Czech Republic; fatka@natur.cuni.cz・Volker Wilde, Research Institute Senckenberg, Palaeobotany, Senckenberganlage 25, D-60325 Frankfurt am Main, Germany; volker.wilde@senckenberg.de

The section at Klonk near Suchomasty (Barrandian area, Central Bohemia, Czech Republic) was approved by the Silurian-Devonian Boundary Committee in 1971 and accepted by the International Commission on Stratigraphy and IUGS at the $24^{\text {th }}$ International Geological Congress in Montreal in 1972 as the global stratotype section and point (GSSP) for the Silurian-Devonian boundary. The stratigraphy, palaeontology, and lithology of the section have been described and discussed in detail in papers by Chlupáč (1971, 1977), Chlupáč et al. (1972), Chlupáč \& Kukal (1977, 1988), Hladil (1991, 1992), Chlupáč \& Hladil (2000), and references therein. Magnetostratigraphy and strontium, carbon, and oxygen isotope data from the boundary interval have been recently studied by Hladíková et al. (1997), Crick et al. (2001), and Frýda et al. (2002).

\section{Geology}

The GSSP is characterized by a comparatively uniform succession without distinct facies changes. The upper Přídolí (Požáry Formation) and the lower Lochkovian (Lochkov Formation) are composed of greyish-black, platy, fine-grained, bituminous limestones alternating with calcareous shale (mudstone) interbeds. Rhythmic alternation of carbonates and mudstones show coarsening and thickening upwards. Sedimentological analyses have suggested rapid deposition (supposed accumulation rates of the order of $20 \mathrm{~m} / \mathrm{Ma}$ ) and the presence of "reworked distal turbidites" for some limestone beds (Hladil 1991, 1992, Crick et al. 2001). The Přídolí-Lochkovian boundary has been placed in the upper part of the limestone bed 20 (Fig. 1).

The Silurian-Devonian boundary at Klonk near Suchomasty has been revisited by drilling new, shallow, and fully cored borehole adjacent to the stratotype section. Both the stratotype section and the core were studied palynologically with respect to the exact position of the boundary within the framework of a multidisciplinary approach, including geochemistry and sedimentology (Mann et al. 2004). The subject of the present paper is a detailed evaluation of prasinophytes and acritarchs of the GSSP and the Klonk-1 borehole (Fig. 1).

\section{Previous research of OWM at the GSSP (Klonk)}

Organic-walled microfossils (OWM) of the GSSP have been studied and/or discussed by several authors. Chitinozoans have proved to be the most indicative OWM for stratigraphic purposes (Paris et al. 1981). At the GSSP, the Silurian-Devonian boundary can be fixed by the FAD (First Appearance Datum) of Angochitina chlupaci 


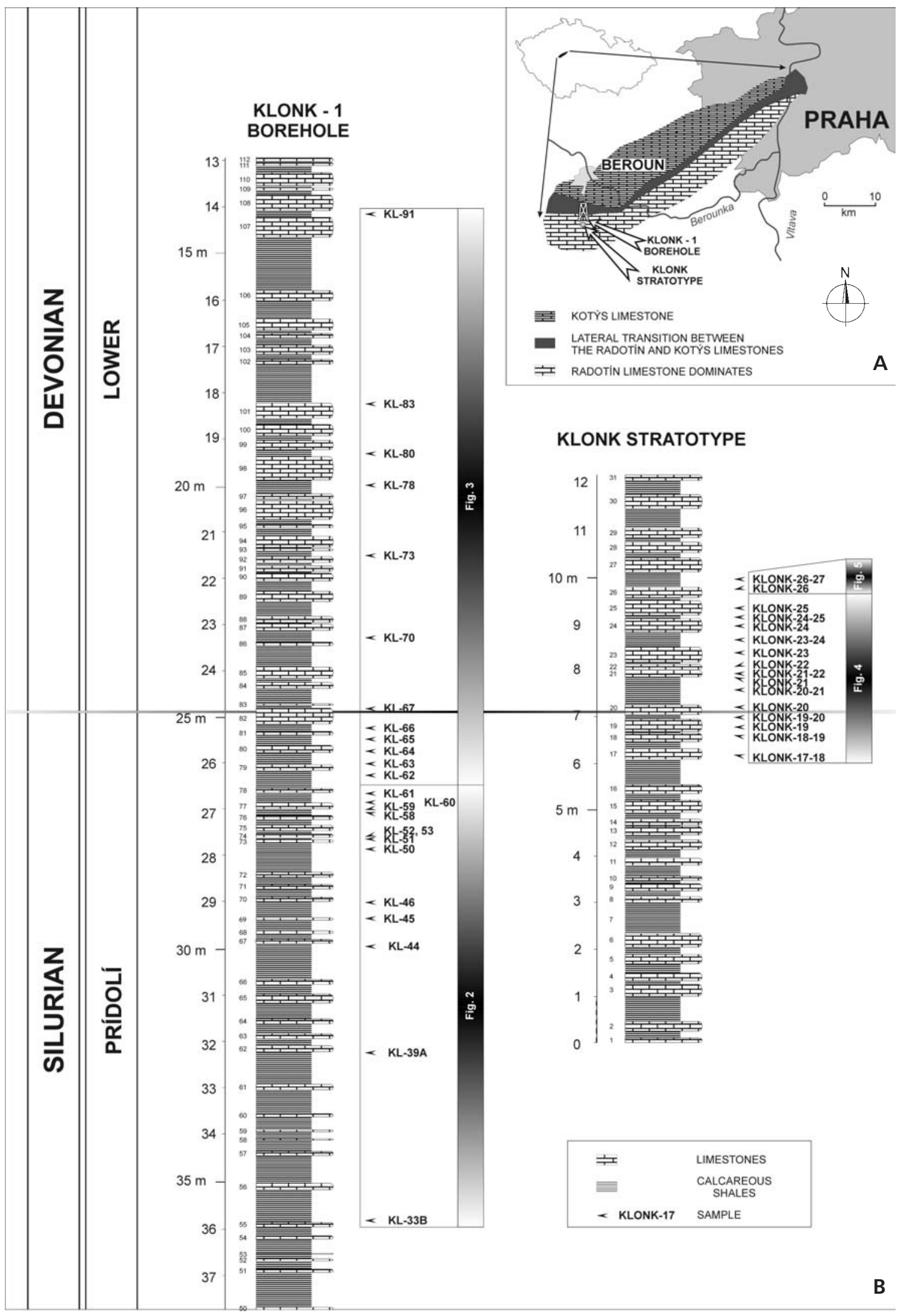

Figure 1. • A - facies distribution in the lower part of the Lower Devonian Lochkov Formation (modified after Chlupáč 1977). B - the Silurian-Devonian boundary interval in the GSSP at Klonk near Suchomasty, with distribution of analyzed samples. 
Paris \& Laufeld, 1981 and the LAD (Last Appearance Datum) of Linochitina klonkensis Paris \& Laufeld, 1981 and Urnochitina urna (Eisenack, 1934) Paris, 1981. The basal Lochkovian is characterized by the FAD of Eisenackitina bohemica (Eisenack, 1934) (after Paris et al. 1981). A distinct accumulation ("acme-zone") of Calpichitina annulata Paris, 1981 within the boundary interval (Fig. 1) was ascertained at the GSSP and at several other sections.

Deunff (1980, p. 490-494) briefly discussed the stratigraphic distribution of 10 taxa of OWM (8 acritarch species and two prasinophytes) in six samples from the GSSP. Paris (1981, p. 61) reports a predominance of Leiosphaeridia and chitinozoans, while acritarchs and spores were very rare or absent. Acritarchs were also mentioned by Richardson et al. (1981, p. 217), who reported the occurrence of "long-ranging palynomorphs such as Leiospheres and Micrhystridia". Le Hérissé (2002, p. 363) discussed the presence of the genus Cymbosphaeridium in the stratotype section of Klonk within the oceanic "Bohemian Magnafacies" of Richardson (1984). Some results of the recent study were preliminarily discussed by Brocke et al. (2002) and Fatka et al. (2003).

\section{Material and methods}

For the present study of OWM, 25 samples were taken from the Klonk-1 borehole (Fig. 1: KL-33B to KL-91) and 16 samples from the stratotype section (Fig. 1: KLONK-17 and 18 to KLONK-26 and 27). All samples were processed by standard methods $(\mathrm{HCl}, \mathrm{HF}$ treatment without oxidation). The remaining organic residue was separated into three fractions of $>63 \mu \mathrm{m},>40 \mu \mathrm{m}$, and $>10 \mu \mathrm{m}$.

Reference slides are stored in the collections of the Research Institute Senckenberg, Palaeobotany, Frankfurt am Main, Germany. The locations of illustrated specimens in slides are based on England-Finder coordinates.

\section{Systematic palaeontology}

\section{Green Algae - Prasinophytes}

Most of the observed OWM are sphaeromorphs without processes and are usually assigned to prasinophytes. However, distinct genera are represented in very different proportions. Leiosphaeridia predominates in all of the studied samples, whereas ?Pleurozonaria occurs only in some levels, and Pterospermella is present in a few samples only. True Tasmanites has not been found.
Genus Leiosphaeridia Eisenack 1958, emend. Downie \& Sarjeant 1963

Type. - Leiosphaeridia baltica Eisenack 1958

Description. - Simple sphaerical phycomata without any ornamentation are assigned to Leiosphaeridia. Most of the individual specimens are comparatively thin-walled.

\section{Leiosphaeridia spp.}

Figures 2, 3, 5A-K, M, N, 6, 7

Description. - Several thousand observed specimens show very wide morphologic variations. The spectrum ranges from small $(10 \mu \mathrm{m})$ to very large specimens (about $700 \mu \mathrm{m}$ in diameter), and from thin-walled and subtle (Figs 5D, E) to thick-walled and very robust forms (e.g. Figs 5B, I, M, N). No relation between the thickness of the wall and the diameter of the central body has been established.

The complete spectrum of small to very large morphotypes is present in some of the samples (e.g. KLONK-19, KLONK-21-22). $90 \%$ of the observed specimens are smaller than $250 \mu \mathrm{m}$ in all samples. However, in three samples (KL-63, KL-65 and KLONK-20) two distinct populations can be recognized.

\section{Genus Pleurozonaria Wetzel 1933}

\section{Type. - Pleurozonaria globula Wetzel 1933}

Diagnosis. - Palaeozoic prasinophytes with canals or pores are usually classified within the genus Tasmanites. However, the family Tasmanacea Sommer 1956 emend. Mädler 1963 is characterized by pore canals and incorporates several other genera. Our material from the GSSP shows a morphology similar to the specimens described by Mädler (1963) from the Jurassic Posidonia Shales and assigned to Pleurozonaria Wetzel 1933. The opinion on validity of the genus Pleurozonaria has been summarized by Fensome et al. (1990, p. 395) and is followed here. The original diagnosis by $\mathrm{O}$. Wetzel emphasized the presence of a polar opening ("Polöffnung"), which was also mentioned by Mädler (1963, p. 332). In some of the specimens of both of our morphotypes, a circular opening has been observed (compare Figs 11C, K, L). The diameter of the opening ranges between $1 / 5$ and $1 / 3$ of the phycoma diameter.

Due to the state of preservation, a direct comparison to the material figured and described by Mädler (1963) is impossible, and thus the generic assignment of our material must remain uncertain. 
Bulletin of Geosciences • Vol. 81, 1, 2006
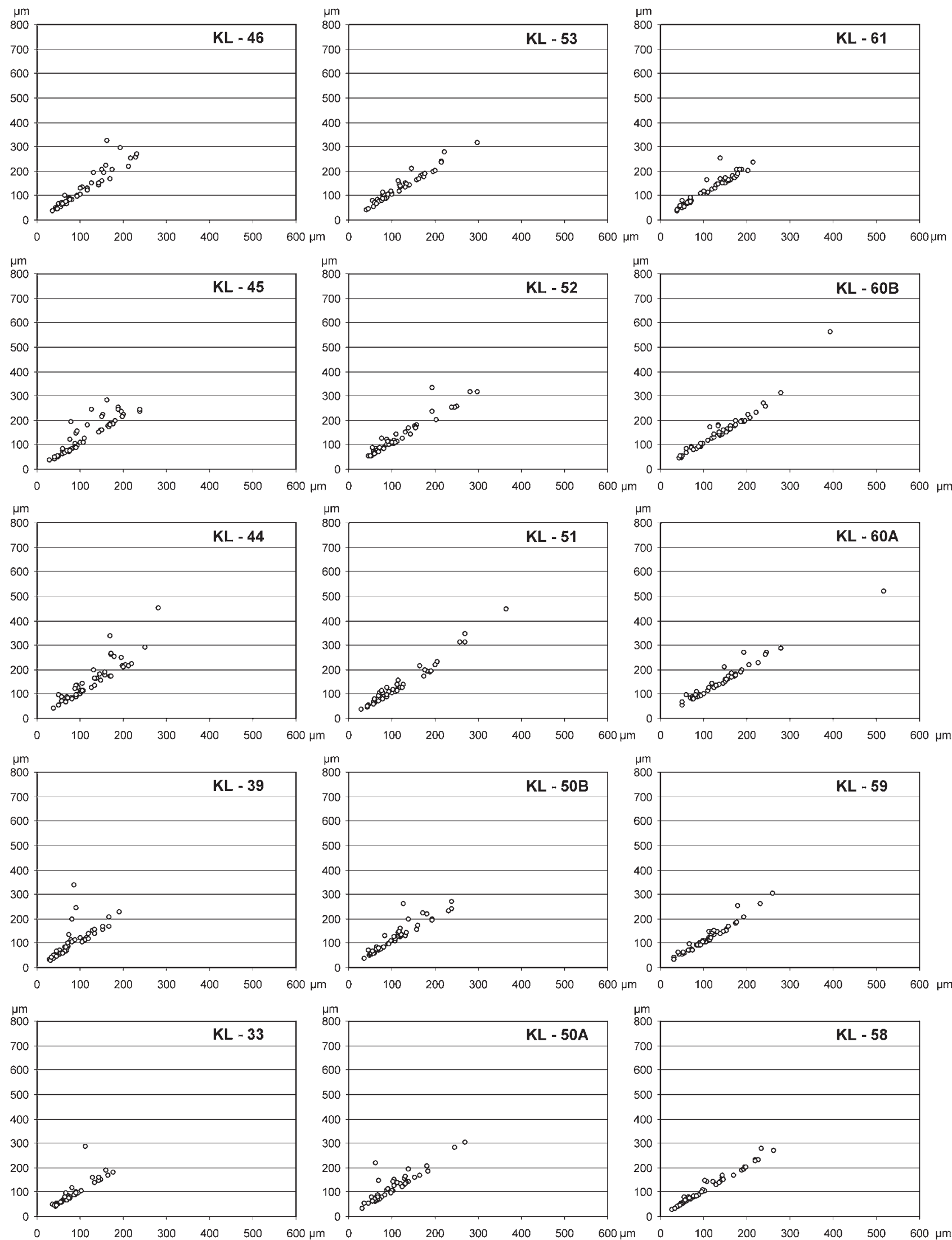

Figure 2. Variation of the diameters (maximum versus minimum) of the central body for Leiosphaeridia spp. in samples KL-33 to KL-61 of the Klonk-1 borehole. 

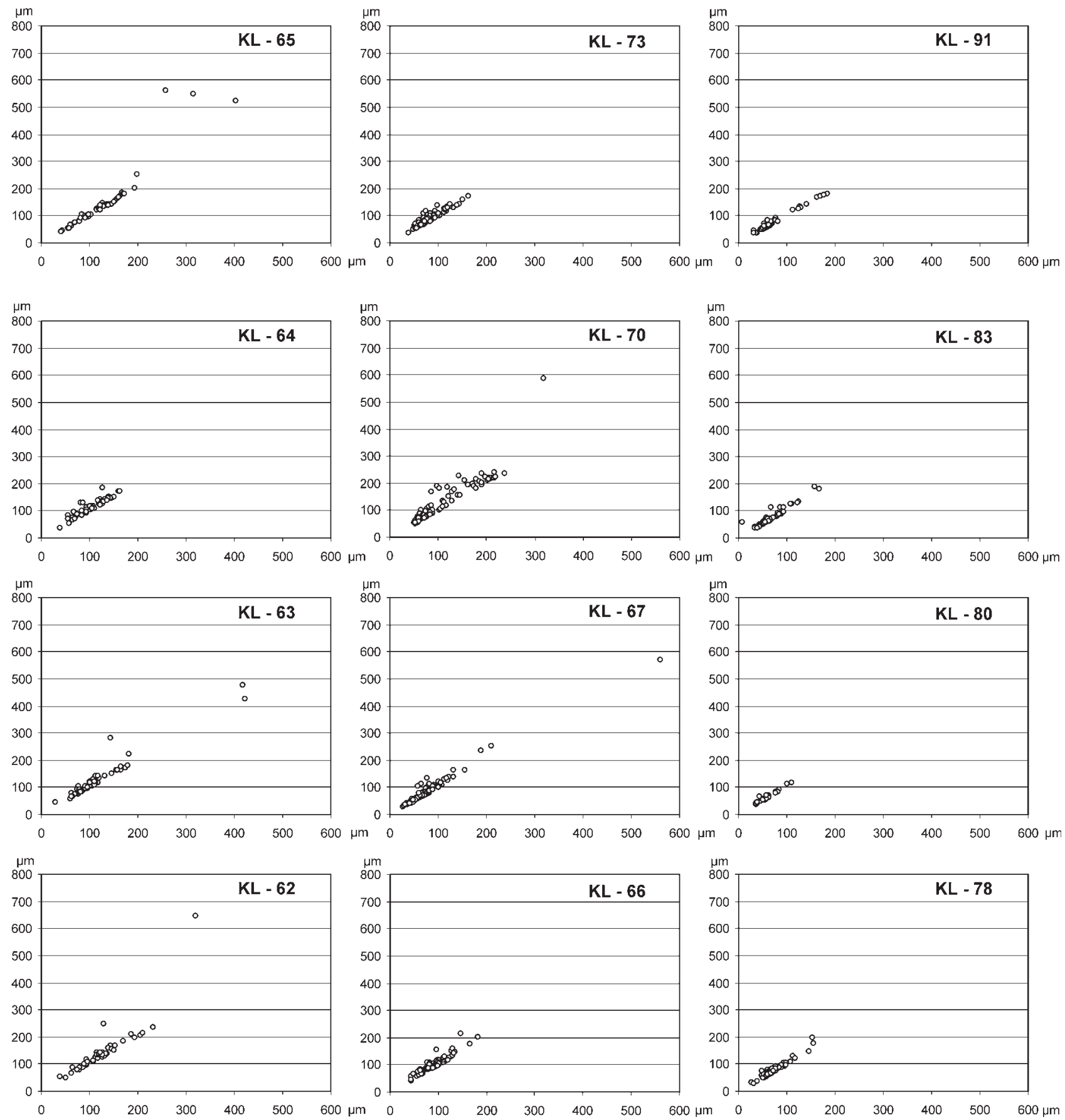

Figure 3. Variation of the diameters (maximum versus minimum) of the central body for Leiosphaeridia spp. in samples KL-62 to KL-91 of the Klonk-1 borehole.

\section{?Pleurozonaria morphotype 1}

Figures 11A, B, D, E

Description. - This morphotype is characterized by a regular and comparatively foveolate to fine reticulate surface. The diameter of the vesicle ranges from 70 to $91 \mu \mathrm{m}$. Single canals are sometimes visible in the centre of each depression. The diameter of individual canals does not exceed $1.5 \mu \mathrm{m}$.

\section{?Pleurozonaria morphotype 2}

Figures $11 \mathrm{C}, \mathrm{F}-\mathrm{L}$

Description. - This morphotype shows a regular but always fine reticulate surface like that observed in morphotype 1, but the ridges of the reticulum are narrower and the individual canals are larger, ranging between 1.8 and $3 \mu \mathrm{m}$ in diameter. The diameter of the vesicle ranges from 73 to $105 \mu \mathrm{m}$. 


\section{Genus Pterospermella Eisenack 1972}

Type. - Pterospermella aureolata (Cookson \& Eisenack 1958) Eisenack 1972

Diagnosis. - The genus Pterospermella is mainly characterized by an ovoidal to subsphaerical central body surrounded by a conspicuous velum displaying radial folds or ribs.

\section{Pterospermella sp.}

Figures 5K, L

Description. - Four specimens of this genus have been found in samples KLONK-20 and KL-51. The central body diameter ranges from 65 to $85 \mu \mathrm{m}$, while the diameter of the velum is between 125 and $208 \mu \mathrm{m}$.

\section{Acritarcha}

\section{Genus Buedingisphaeridium Schaarschmidt 1963 emend. Staplin et al. 1965 emend. Lister 1970}

Type. - Buedingisphaeridium permicum Schaarschmidt 1963

Diagnosis. - This genus is characterized by sphaerical central body covered by numerous short conical and hollow processes.

\section{cf. Buedingisphaeridium sp. \\ Figure 9H}

Description. - The observed specimen bears short hollow, distally solid conical processes. The central body measures $34 \mu \mathrm{m}$ in diameter. Due to the poor state of preservation a final determination is not possible.

\section{Genus Cymbosphaeridium Lister 1970}

Type. - Cymbosphaeridium bikidium Lister 1970

Remarks. - Cymbosphaeridium is characterized by a double-walled central body, distally branched processes, and the presence of a large opening covered by a process bearing an operculum.

The genus includes about 10 species ranging from the Silurian (Llandovery) to the early Devonian (Le Hérissé, personal communication). From the GSSP at Klonk, Deunff (1980, fig. 6) reported Cymbosphaeridium pilar (Cramer 1964) Lister 1970 in bed number 5, and $C$. cariniosum (Cramer 1964) Jardiné et al. 1972 in beds 5, 10, and 20. The recently studied specimens show important differences in diameter of the central body and length of the processes. Therefore, they could not be assigned to any of the previously described species. But, two distinct morphotypes may be distinguished (Fig. 8).

\section{Cymbosphaeridium morphotype 1}

Figure 4

Description. - In the four specimens the central body diameter ranges between $17-21 \mu \mathrm{m}$, and the length of processes ranges between $7-11 \mu \mathrm{m}$.

\section{Cymbosphaeridium morphotype 2}

Figures 4, 9A-E, G, J, K, N

Description. - 42 specimens, central body diameter ranges between 24 and $39 \mu \mathrm{m}$ (mean 31,4 $\mu \mathrm{m}$ ), the length of processes ranges between 7-20 $\mu \mathrm{m}$.

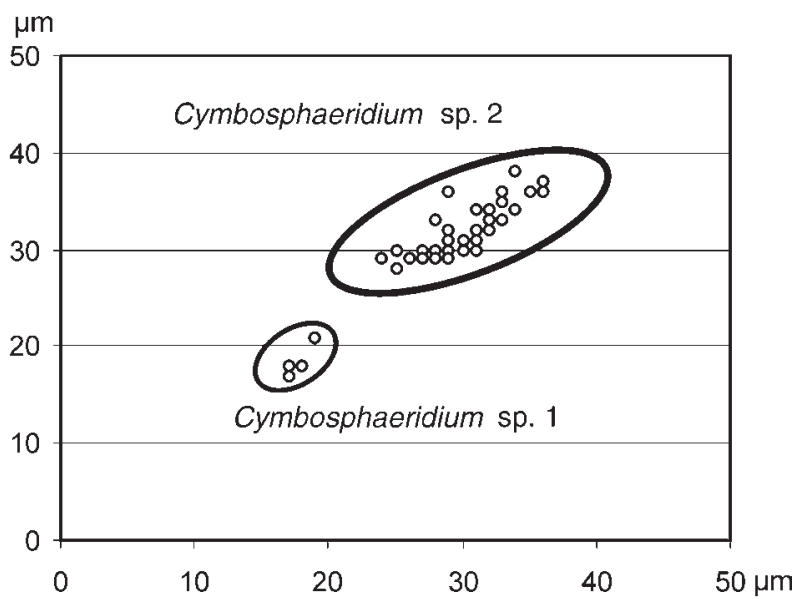

Figure 4. Variations of the diameters (maximum versus minimum) of the central body for Cymbosphaeridium.

Figure 5. Leiospheres and other prasinophytes of the Silurian-Devonian boundary beds at Klonk near Suchomasty. • A - Leiosphaeridia sp., sample KL-53 (H48.1) • B - Leiosphaeridia sp., sample KL-53 (K38). C - Leiosphaeridia sp., sample KLONK-45 (M40.2). D - Leiosphaeridia sp., sample KLONK-20 (S56). E - Leiosphaeridia sp., sample KLONK-21 (M66). • F - Leiosphaeridia sp., sample KLONK-20 (J54). G - Leiosphaeridia sp., sample KLONK-20 (R51.1). • H - Leiosphaeridia sp., sample KLONK-21 (N64). • I - Leiosphaeridia sp., sample KLONK-20 (O48.2). • J Leiosphaeridia sp., sample KLONK-20 (O40.4). $・ \mathrm{~K}-$ Leiosphaeridia sp. and Pterospermella sp., sample KLONK-20 (P52). L - Pterospermella sp., sample KL-51 (N39.3). M - Leiosphaeridia sp., sample KLONK-20 (N33.3). N - Leiosphaeridia sp., sample KLONK-45 (S47). 
Rainer Brocke et al. - Acritarchs and prasinophytes of the Silurian-Devonian GSSP
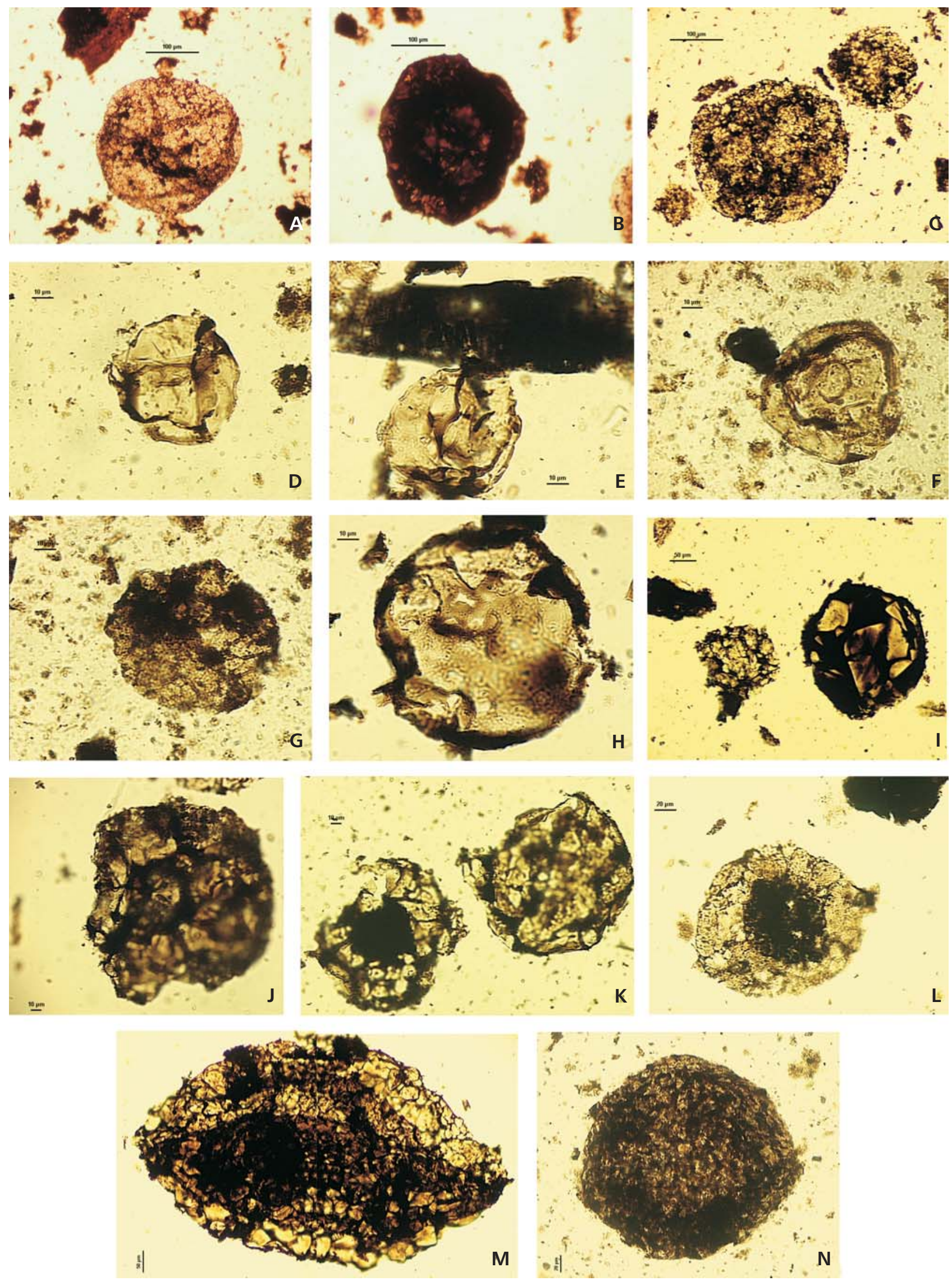
Bulletin of Geosciences • Vol. 81, 1, 2006
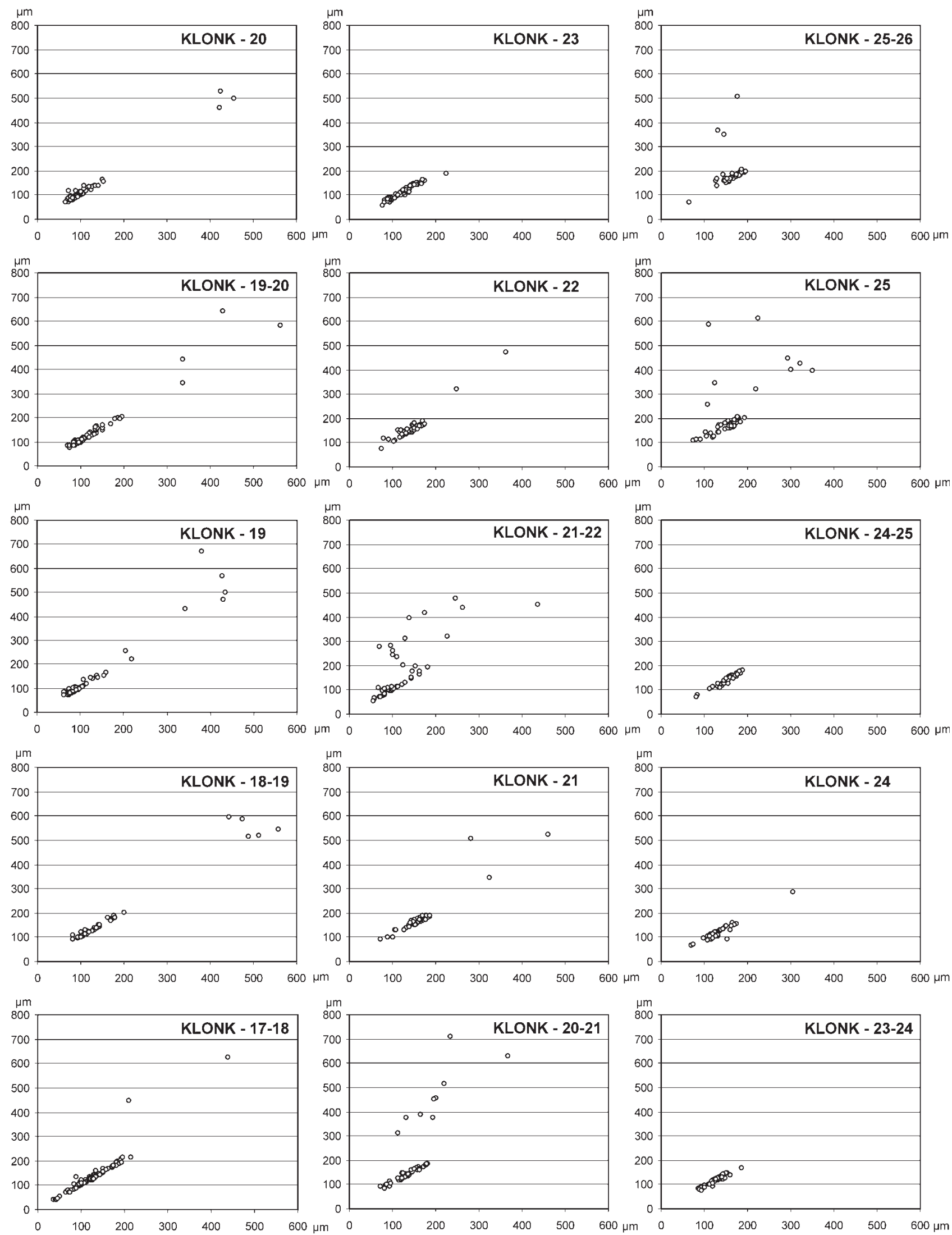

Figure 6. Variation of the diameters (maximum versus minimum) of the central body for Leiosphaeridia spp. in samples KLONK-17-18 to KLONK-25-26 of the Klonk stratotype section. 
Rainer Brocke et al. - Acritarchs and prasinophytes of the Silurian-Devonian GSSP
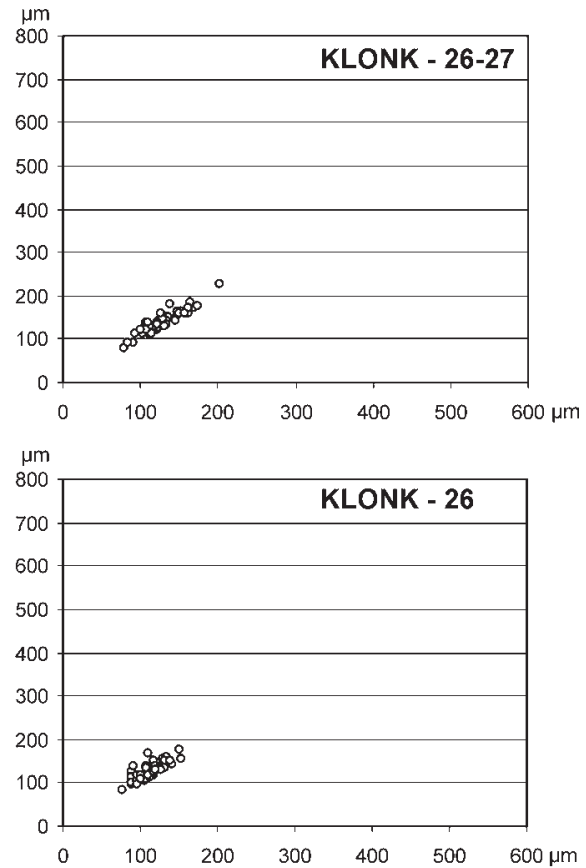

Figure 7. Variation of the diameters (maximum versus minimum) of the central body for Leiosphaeridia spp. in samples KLONK-26 to KLONK-26-27 of the Klonk stratotype section.

\section{Genus Diexallophasis Loeblich 1970}

Type. - Diexallophasis denticulata (Stockmans \& Willière 1963) Loeblich 1970

Diagnosis. - Vesicle sphaerical to subsphaerical, bearing a few to numerous bifurcate to multifurcate processes. Process cavity freely communicates with the vesicle interior. Along the processes, spinous to denticulate ornamentation is developed.

Remarks. - Deunff (1980, fig. 6) mentioned the occurrence of Diexallophasis denticulata (Stockmans \& Willière 1963) Loeblich 1970 in beds 5, 10, and 20 of the GSSP. This cosmopolitan species ranges from the Upper Ordovician (Le Hérissé in Molyneux et al. 1996) to the late Middle Devonian (Wicander in Molyneux et al. 1996).

\section{cf. Diexallophasis sp.}

Figures 9P, Pa

Description. - The two poorly preserved specimens lack the distal parts of processes and can be only provisionally assigned to the genus Diexallophasis.
Genus Multiplicisphaeridium Staplin 1961, restrict. Staplin, Jansonius \& Pocock 1965, emend. Lister 1970

Type. - Multiplicisphaeridium ramispinosum Staplin 1961

Remarks. - Multiplicisphaeridium represents subsphaerical to almost polygonal central bodies with numerous homomorph to heteromorph, distally polyfurcate processes. It differs from Diexallophasis in the lack of wall ornamentation.

\section{Multiplicisphaeridium sp. \\ Figure 9I}

Description. - The central body of the single specimen is sphaerical with 12 heteromorphic processes. The hollow processes freely communicate with the central cavity; distally they are irregularly branched. Central body diameter $27 \mu \mathrm{m}$, the length of processes ranges from 12 to $15 \mu \mathrm{m}$.

\section{Genus Onondagaella (Cramer 1966) Playford 1977}

Type. - Veryhachium asymetricum Deunff 1954

Diagnosis. - Triangular vesicle with three heteromorphic processes, two of which are tapering and spine-like, while the third has a prominent distal circular opening, if closed, designated as epibystra by Playford (1977, p. 30).

Remarks. - Two species of the genus Onondagaella are documented to cross the Silurian-Devonian boundary: O. deunffii Cramer 1966 has been reported to range from the base of the Ludlow (Le Hérissé in Molyneux et al. 1996) to the end of the Lochkovian (Le Hérissé et al. 2000); O. assymetrica (Deunff 1954 ex Deunff 1961) Cramer, 1966 ranges from pre-Přídolí levels (Le Hérissé et al. 2000) to the end of the Emsian (Wicander in Molyneux et al. 1996).

\section{Onondagaella aff. assymetrica (Deunff 1954 ex Deunff 1961) Cramer 1966 \\ Figures 10B, C}

Description. - The two discovered specimens are similar to O. assymetrica in terms of dimensions $(38 \times 43 \mu \mathrm{m}$ and $52 \times 60 \mu \mathrm{m})$ and general morphology. 
Onondagaella sp.

Figure 10A

Description. - The central body of the single observed specimen measures 51 $\times 66 \mu \mathrm{m}$.

\section{Genus Oppilatala Loeblich \& Wicander 1976}

Type. - Oppilatala vulgaris Loeblich \& Wicander 1976

Remarks. - The genus Oppilatala is characterized by a circular central body with a variable number of distally multifurcate processes. It differs from Multiplicisphaeridium by its proximally plugged processes, and from Cymbosphaeridium by the absence of a large circular opening and process bearing operculum.

\section{Oppilatala sp.}

Figure 90

Description. - The figured specimen (Fig. 90) is comparatively well preserved. The diameter of the central body is between 22 and $27 \mu \mathrm{m}$; there are at least five processes between 18 and $30 \mu \mathrm{m}$ in length. Two other specimens (Figs 9L, M) show comparable dimensions, but because of poor preservation they are only tentatively assigned to the genus Oppilatala.

\section{Mazuelloids}

In addition to acritarchs and prasinophytes, mazuelloids have been found in four levels. In samples KLONK-19 and KLONK-20, broken pieces and/or complete long processes are quite common in comparison to much more rarely observed complete specimens. In samples KLONK-23-24, KLONK-24, and KLONK-26, only a few complete specimens of varieties with short processes have been noted.

\section{Conclusions}

Acritarchs and prasinophytes have systematically been evaluated from the Silurian-Devonian GSSP at Klonk and the Klonk-1 borehole (both near Suchomasty, Fig. 1) for the first time.

Acritarchs. - Knowledge on late Silurian to early Devonian acritarchs is generally very limited. This is especially true for deep-water deposits on the margins of the Rheic Ocean (Richardson 1984, Le Hérissé 2002), which have been called the "Bohemian Magnafacies" by Richardson (1984). The extensive reinvestigation of the stratotype section, and the adjacent borehole also confirmed the presence of poorly preserved and less diversified acritarch assemblages. The new data could not improve the poor stratigraphic potential of acritarchs across the Silurian-Devonian boundary within the "Bohemian Magnafacies".

Figure 9. Acritarchs of the Silurian-Devonian boundary beds at Klonk near Suchomasty. • A - operculum of Cymbosphaeridium morphotype 2, sample KLONK-18-19 (F33). • B - Cymbosphaeridium morphotype 2, sample KLONK-24 (H34). • C - Cymbosphaeridium morphotype 2, sample KLONK-19-20 (T44.4). • D - Cymbosphaeridium morphotype 2, sample KLONK-18-19 (W42.3). E - Cymbosphaeridium morphotype 2, sample KLONK-19-20 (W34.3). • F - gen. et sp. indet., sample KLONK-20 (P52.3). • G - Cymbosphaeridium morphotype 2, sample KLONK-19-20 (V48.3). - H - cf. Buedingisphaeridium sp., sample KLONK-19-20 (Q33). • I - Multiplicisphaeridium sp., sample KLONK-18-19 (W38.3). • J ?Cymbosphaeridium morphotype 2, sample KLONK-20 (C52.3). • K - Cymbosphaeridium morphotype 2, sample CZ-KL-53 (V48.2). • L - cf. Oppilatala sp., sample KLONK-19 (S32.1). M - cf. Oppilatala sp., sample KLONK-19 (Q46). • N - Cymbosphaeridium morphotype 2, sample KL-53 (T38.2). $\bullet \mathrm{O}$ - Oppilatala sp., sample KL-53 (R42.3). P , Pa - cf. Diexallophasis sp., sample KLONK-23A II (Y50.3). 
Rainer Brocke et al. - Acritarchs and prasinophytes of the Silurian-Devonian GSSP
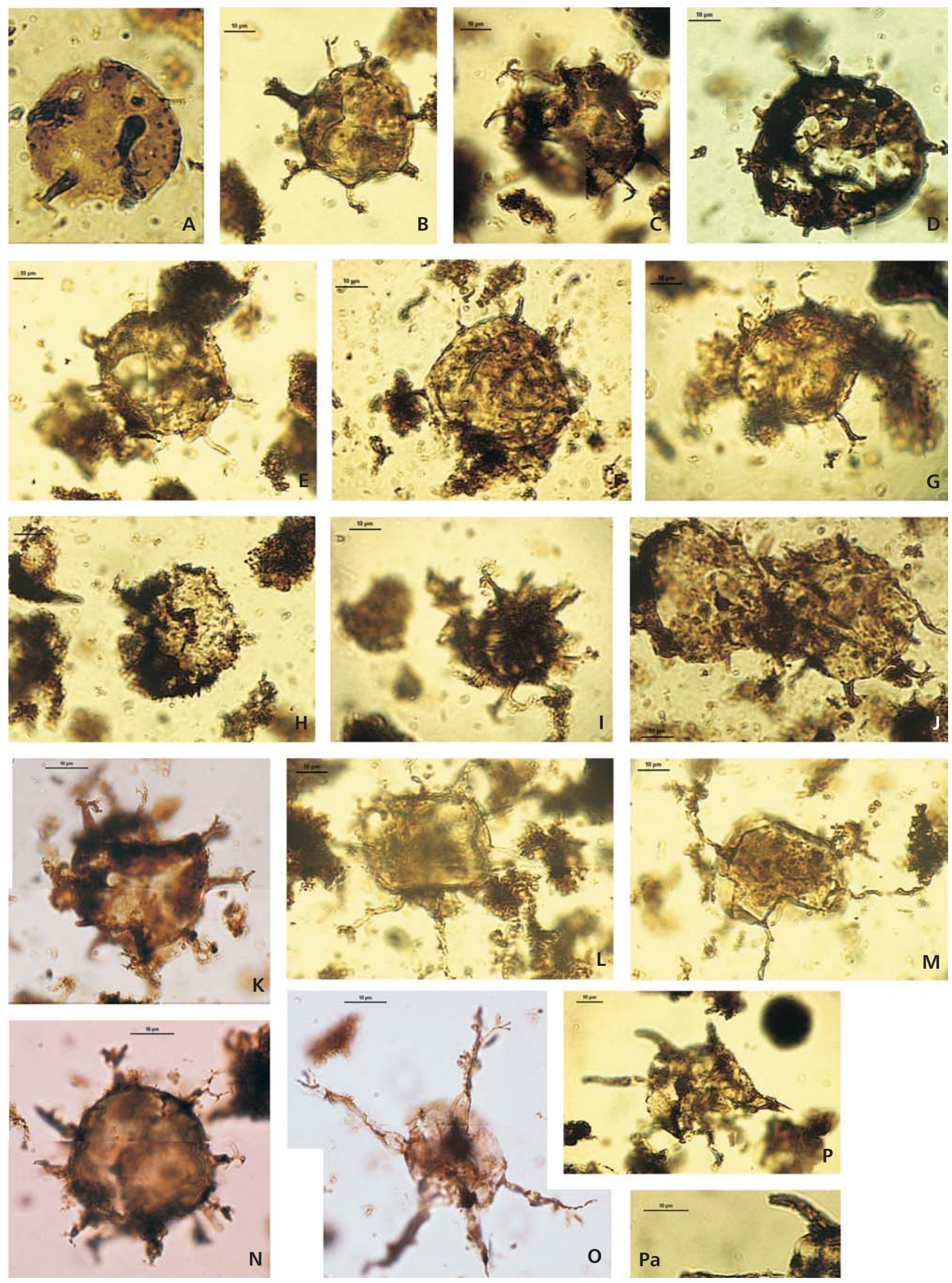

4. $2^{2}+8$
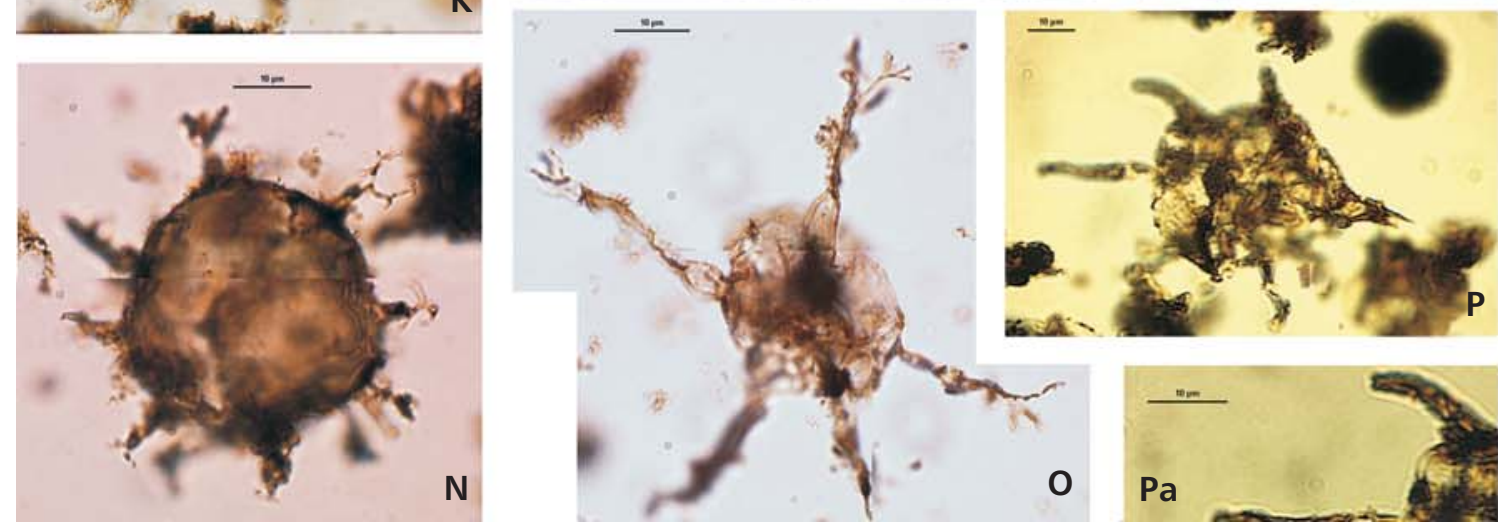
Prasinophytes. - In contrast to acritarchs, prasinophytes are widely distributed in all studied samples, particularly within the boundary interval. They have been assigned to the following taxa: Leiosphaeridia spp., ?Pleurozonaria morphotype 1, ?Pleurozonaria morphotype 2 and Pterospermella sp.

Our measurements of more than 2000 specimens of Leiosphaeridia spp. (Figs 2, 3, 6, 7) from the stratotype and the borehole show a general trend regarding changes in size.

Leiospheres from the upper Přídolí generally measure less than $300 \mu \mathrm{m}$ in diameter (KL-33 to KL-62). In the uppermost part of the Přídolí and the lowermost Lochkovian (KL-63 to KL-70) the diameter is generally smaller than $250 \mu \mathrm{m}$, and higher up in the sequence it does not exceed $200 \mu \mathrm{m}$ (KL-73 to KL-91). In some samples (KL-33, KL-44, KL-52, KL-60, KL-62, KL-63, KL-65, KL-67, KL-70) very large specimens occasionally occur. They are absent above sample KL-70. The largest specimens are concentrated around the Silurian-Devonian boundary. A comparable trend is apparent in samples from the stratotype.

Richardson (1984, p. 341) defined the "Bohemian Magnafacies" as follows: "Deeper water deposits, at times oceanic, often consisting of black shales containing only pelagic microfossils (Bohemian Magnafacies), are characterized by prasinophycean 'cysts', frequently in great abundance, in chitinozoa while miospores and acritarchs in this magnafacies are rare." In addition, the frequent occurrence of mazuelloids is to be mentioned as characteristic of this type of facies.

Mazuelloids. - A recently published interpretation of the common occurrence of mazuelloids, as observed in the lower Silurian of the Holy Cross Mountains in Poland (Kremer 2005), seems to fit with the trophic changes driven by uppwellings.

Phytoplankton cysts at the Silurian-Devonian boundary GSSP at Klonk are specifically represented by acritarchs and prasinophytes, and questionably also by mazuelloids - see discussion of the origin of mazuelloid in Kremer (2005). Fluctuation in the frequency of these groups may have been related to transgressive/regressive pulses, which have been repeatedly recorded for the Silurian-Devonian boundary interval (Crick et al. 2001). Controversy, however, continues as to whether the boundary itself was characterized by a transgression (Mann et al. 2001) or regression (Saltzmann 2002).

\section{Acknowledgements}

The study was funded by the German Research Foundation (DFG) as part of the projects MA 1861/2-2 and BR 1943/3-1, and the Humboldt Foundation (V-8121/TSR/1007014). Thanks are due to the Research Centre Jülich (U. Mann) for drilling the borehole at Klonk and access to the core material. This is a contribution to the IGCP project 499 "Devonian land-sea interaction: evolution of ecosystems and climate". A. Le Hérissé (Brest) and J. Kalvoda (Brno) reviewed the manuscript and offered suggestions that improved the final submission.

\section{References}

Brocke, R., Wilde, V., FatKa, O. \& Mann, M. 2002. Chitinozoa and acritarchs at the Silurian/Devonian boundary: Examples from the Barrandian area. Proceedings of the International Paleontological Congress 2002, Sydney, Geological Society of Australia, Abstracts 68, 192.

CHLuPÁČ, I. 1971. Some trilobites from the Silurian/Devonian boundary beds of Czechoslovakia. Palaeontology 14(1), 159-177.

ChlupÁč, I. 1977. Barrandian, 84-95. In MARTinsson, A. (ed.) The Silurian-Devonian boundary. IUGS Series A 5.

CHLUPÁČ, I. \& HLADIL, J. 2000. The global stratotype section and point of the Silurian-Devonian boundary. Courier Forschungsinstitut Senckenberg 225, 1-7.

Chlupáč, I., Jaeger, H. \& Zikmundová, J. 1972. The Silurian-Devonian boundary in the Barrandian. Bulletin of Canadian Petroleum Geology 20, 104-174.

Chlupáč, I., \& KuKal, Z. 1977. The boundary stratotype at Klonk, 96-109. In MARTinsson, A. (ed.) The Silurian-Devonian Boundary. IUGS Series A 5.

ChlupáČ, I. \& KuKal, Z. 1988. Possible global events and the stratigraphy of the Barrandian Paleozoic (Cambrian-Devonian, Czechoslovakia). Sborník geologických věd, Geologie 43, 83-146.

Crick, R.E., Ellwood, B.B., Hladil, J., El-Hassani, A., Hrouda, F. \& ChlupÁČ, I. 2001. Magnetostratigraphy susceptibility of the Přídolian-Lochkovian (Silurian-Devonian) GSSP (Klonk, Czech Republic) and a coeval sequence in Anti-Atlas Morocco. Palaeogeography, Palaeoclimatology, Palaeoecology 167, 73-100.

DeUnFF, J. 1980. Le paléoplancton des Grés de Landévennec

Figure 10. Acritarchs, mazuelloids and problematica of the Silurian-Devonian boundary beds at Klonk near Suchomasty. $\bullet$ A - Onondagaella sp., sample KLONK-26-I (Y35.4) • B - Onondagaella aff. assymetrica (Deunff 1954 ex Deunff 1961) Cramer 1966, sample KLONK-19 (B35.4). • C Onondagaella aff. assymetrica (Deunff 1954 ex Deunff 1961) Cramer 1966, sample KLONK-19 (T47). • D - Mazuelloid sp., sample KL-50-A (F37). - E - Mazuelloid sp., sample KL-59 (U37.2). • F - Mazuelloid sp., sample KL-59 (Q37.3). • G, H - Mazuelloid sp., sample KL-53 (M43.1). • I Mazuelloid sp., sample KL-50B (Q50). • J - Tersisphaera sp., sample KL-53 (H48.1). $\bullet$ K - Mazuelloid sp., sample KL-51 (W51.3). $\bullet$ L - Tersisphaera sp., sample KL-53 (H48.1). M - Porcatitubulus sp., sample KLONK-20-21 (P51). • N, O - animal cuticule, sample KL-53 (G46.2). 
Rainer Brocke et al. • Acritarchs and prasinophytes of the Silurian-Devonian GSSP
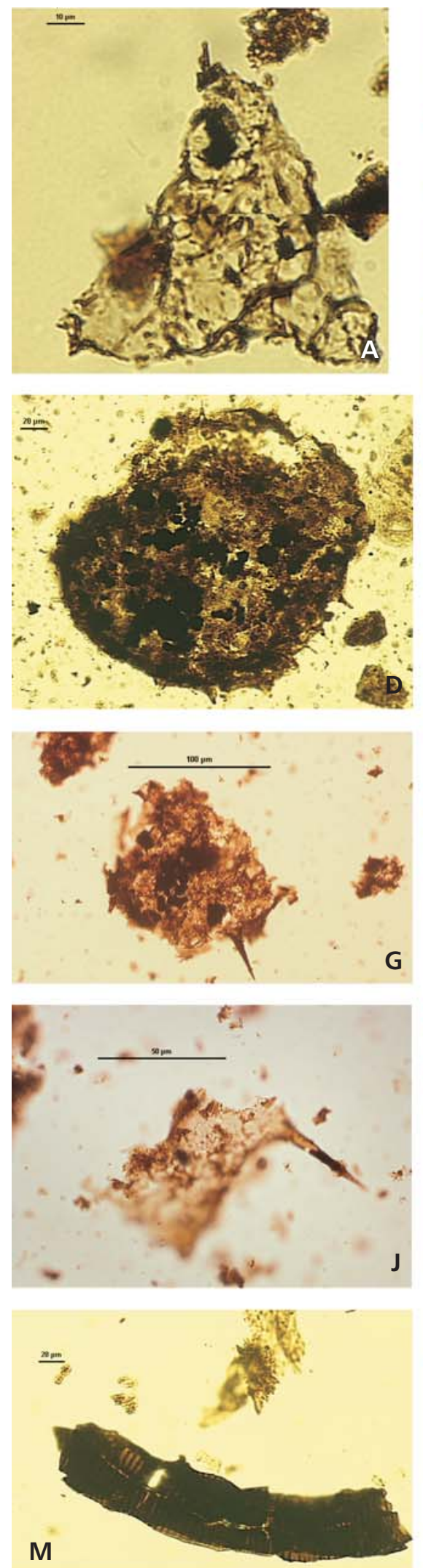
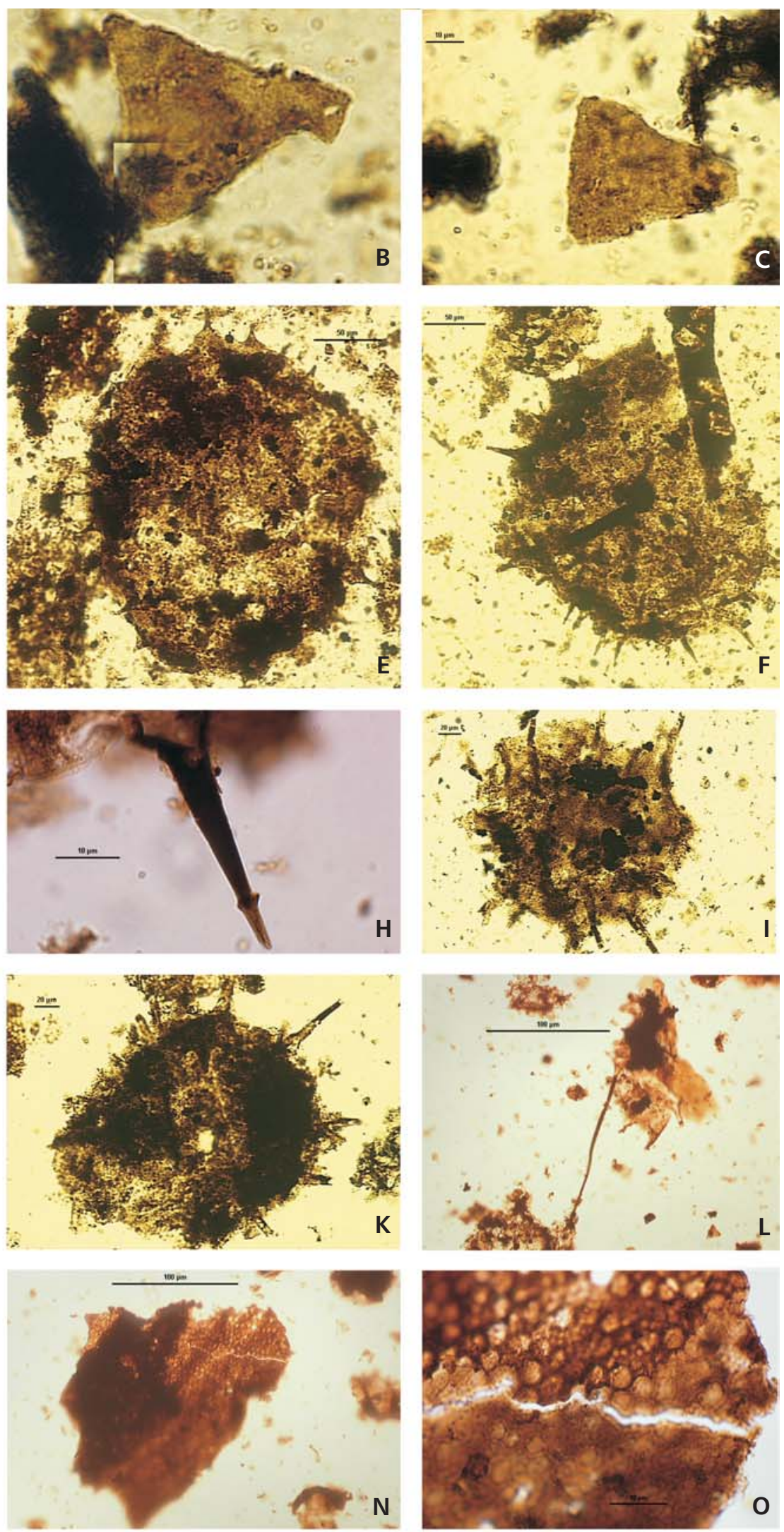
(Gedinnien de la Rade de Brest, Finistère) étude biostratigraphique. Geobios 13, 483-539.

FAtKa, O., Brocke, R. \& Wilde, V. 2003. Organic-walled microfossils at the Silurian/Devonian boundary stratotype (Klonk near Suchomasty, Barrandian area, Czech Republic). In Ortega, G. \& Acenolaza, G.F. (eds) Proceedings of the $7^{\text {th }}$ International Graptolite Conference and Field Meeting of the International Subcommission on Silurian Stratigraphy, INSUGEO, Series Correlación Geológica 18, 125-128.

Fensome, R.A., Williams, G.L., Barss, M.S., Freeman, J.M. \& HILl, J.M. 1990. Acritarchs and fossil prasinophytes: an index to genera, species and intraspecific taxa. American Association of Stratigraphic Palynologists, Contribution Series 25, 1-771.

FRÝdA, J., HLADIL, J. \& VOKURKA, K. 2002. Seawater strontium isotope curve at the Silurian/Devonian boundary: a study of the global Silurian/Devonian boundary stratotype. Geobios 35(1), 21-28.

HLADIL, J. 1991. Evaluation of the sedimentary record in the Silurian/Devonian boundary stratotype at Klonk (Barrandian area, Czechoslovakia). Newsletters on Stratigraphy 25, 115-125.

HLADIL, J. 1992. Are there turbidites in the Silurian/Devonian boundary stratotype? (Klonk near Suchomasty, Barrandian, Czechoslovakia). Facies 26, 35-54.

Hladíková, J., Hladil, J. \& KŘíbeK, B. 1997. Carbon and oxygen isotope record across the Přídolí to Givetian stage boundaries in the Barrandian Basin (Czech Republic). Palaeogeography, Palaeoclimatology, Palaeoecology 132, 225-241.

KREMER, B. 2005. Mazuelloids: Product of post-mortem phosphatization of acanthomorphic acritarchs. Palaios 20, 27-36.

LE HÉrissé, A. 2002. Paleoecology, biostratigraphy and biogeoegraphy of late Silurian to early Devonian acritarchs and prasinophycean phycomata in well A161, Western Libya, North Africa. Review of Palaeobotany and Palynology 118(1-4), 359-395.

Le Hérissé, A., Servais, T. \& WicAnder, R. 2000. Devonian acritarchs and related forms, 195-205. In BULTYNCK, P. (ed.) Subcommission on Devonian Stratigraphy. Fossil groups important for boundary definition. Courier Forschungsinstitut Senckenberg 220.

LISTER, T.R. 1970. A monograph of the acritarchs and chitinozoa from the Wenlock and Ludlow series of the Ludlow and Millichope areas, Shropshire. Palaeontographical Society (Monograph) 124(1), 1-100.

LOEBLICH, A.R. Jr. 1970. Morphology, ultrastructure and distribution of Paleozoic acritarchs. Proceedings of the North American Paleontological Convention, Chicago G, 705-788.
Mann, U., Herten, U., Kranendonck, O., Poelchau, H.S., Stroetmann, J., Vos, H., SuchÝ, V., Brocke, R., Wilde, V., Muller, A., Ebert, J., BozdoĞan, N., Soylu, C., El-Hassani, A. \& YalçIn, M.N. 2001. Dynamics of the Silurian/Devonian boundary sequence: Sedimentary cycles vs. Organic matter variation. Terra Nostra 4, 44-48.

Mann, U., Herten, U., Kranendonck, O., BozdoĞan, N., Brocke, R., Ebert, J., El-Hassani, A., Poelchau, H.S., SchaEFER, R.G., SOYlu, C., Vos, H., Wilde, V. \& Yalçin, M.N. 2004. Chemostratigraphy of Silurian/Devonian boundary sequences: Significance of sedimentary cycles, environment and bioproductivity. International Meeting on Stratigraphy, Rabat, March 1-10, Abstracts, 31-35.

MÄDLER, K.A. 1963. Die figurierten organischen Bestandteile der Posidonienschiefer. Geologisches Jahrbuch, Beihefte 58, 287-406.

MolyneuX, S.G., Le HérisSÉ, A. \& WiCANDER, R. 1996. Chapter 16: Paleozoic phytoplankton, 493-529. In JANSONIUS, J. \& McGregor, D.C. (eds) Palynology, Principles and applications, 2. American Association of Stratigraphic Palynologists Foundation.

PARIS, F. 1981. Les Chitinozaires dans le Paléozoique du Sud-Ouest de l'Europe (Cadre géologique - Étude systématique - Biostratigraphie). Mémoires de la Société géologique et minéralogique de Bretagne 26, 1-412.

PARIS, F., LAufeld, S. \& CHLUPÁČ, I. 1981. Chitinozoa of the Silurian-Devonian boundary stratotypes in Bohemia. Sveriges Geologiska Undersökning, Serie C, 4(51), 1-29.

PlAYFORD, G. 1977. Late Devonian acritarchs of the Moose River Basin, Ontario. Bulletin of the Geological Survey of Canada $279,1-87$.

RichaRdson, J.B. 1984. Mid-Paleozoic palynology, facies and correlation. Proceedings of the $27^{\text {th }}$ International Geological Congress, Volume 1, 341-365.

RichaRdSON, J.B., RASUl, M. \& Al-AMERI, T. 1981. Acritarchs, miospores and correlation of the Ludlowian-Downtonian and Silurian-Devonian boundaries. Review of Palaeobotany and Palynology 34, 209-224.

SAltzmann, M.R. 2002. Carbon isotope $\left(\delta^{13} \mathrm{C}\right)$ stratigraphy across the Silurian-Devonian transition in North America: evidence for a perturbation of the global carbon cycle. Palaeogeography, Palaeoclimatology, Palaeocology 187, 83-100.

WetZEL, O. 1933. Die organischer Substanz erhaltenen Mikrofossilien des baltischen Kreide-Feuersteins mit einem sediment-petrographischen und stratigraphischen Anhang. Palaentographica, Abt. A 78, 1-110.

Figure 11. Prasinophytes of the Silurian-Devonian boundary beds at Klonk near Suchomasty. • A - ?Pleurozonaria morphotype 1, KLONK-18-19 (Q38.3). B - ?Pleurozonaria morphotype 1, KLONK-18-19 (R34). • C - ?Pleurozonaria morphotype 2, KLONK-18-19 (Q40). D - ?Pleurozonaria morphotype 1, KLONK-18-19 (R33). • E, Ea - ?Pleurozonaria morphotype 1, KLONK-18-19 (Z49.2). • F - ?Pleurozonaria morphotype 2, KLONK-18-19 (X42.1). G, Ga - ?Pleurozonaria morphotype 2, KLONK-18-19(Y44.4). $•$ - ?Pleurozonaria morphotype 2, KLONK-18-19 (X41.4). - I - ?Pleurozonaria morphotype 2, KL-51 (O43.2). • J - Pleurozonaria morphotype 2, KL-51 (U56.3). • K - ?Pleurozonaria morphotype 2, KLONK-18-19 (X42.1). L, La, Lb - ?Pleurozonaria morphotype 2, KLONK-18-19 (G39). 
Rainer Brocke et al. - Acritarchs and prasinophytes of the Silurian-Devonian GSSP
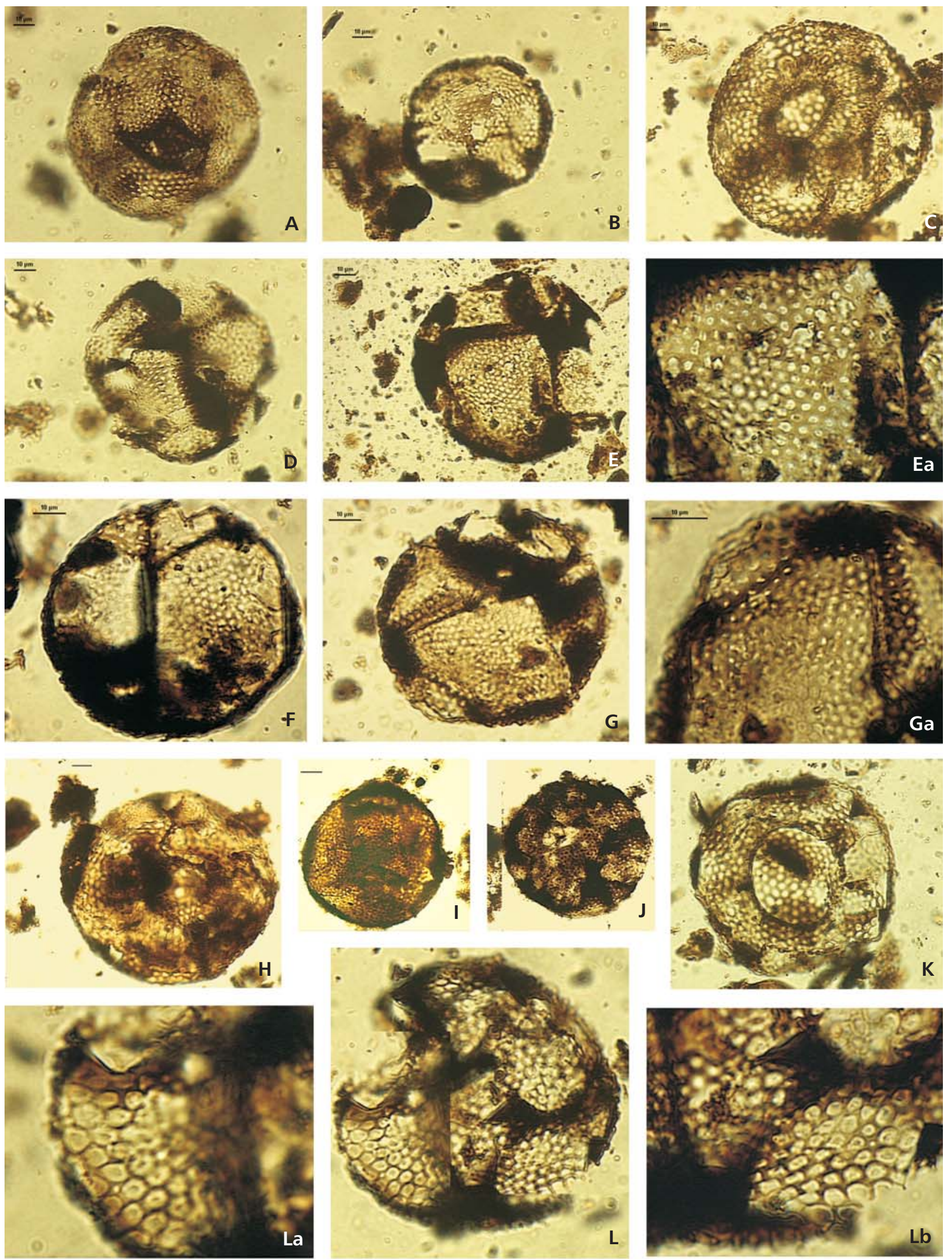